\title{
Growth and Phenology of Barley as Influenced by Various Nutrient Management Practices
}

\author{
Sandeep Kumar*, Meena Sewhag, Shweta, Uma Devi and Neelam \\ Department of Agronomy, CCS Haryana Agricultural University, Hisar, Haryana, India \\ *Corresponding author
}

\section{A B S T R A C T}

\begin{tabular}{l} 
Keyw or d s \\
Phenology of \\
$\begin{array}{l}\text { Barley (Hordeum } \\
\text { vulgare L.), } \\
\text { Vermicompost }\end{array}$ \\
\hline Article Info \\
$\begin{array}{l}\text { Accepted: } \\
\text { 22 June } 2020 \\
\text { Available Online: } \\
\text { 10 July } 2020\end{array}$ \\
\hline
\end{tabular}

A field experiment entitled, Growth and phenology of barley as influenced by various nutrient management practices was conducted during the Rabi season of 2017-2018 at the Research Farm of department of Agronomy, Chaudhary Charan Singh Haryana Agricultural University, Hisar with the objective to study the effect of integrated nutrient management practices on growth and phenology of barley. The experimental field soil was sandy loam in texture, slightly alkaline in reaction, low in organic carbon and nitrogen, medium in available potassium and phosphorus. The experiment was laid out in Randomized Block Design replicated thrice with ten different treatments viz. $\mathrm{T}_{1}(\mathrm{Control})$, $\mathrm{T}_{2}$ (Biomix), $\mathrm{T}_{3}$ (Vermicompost @ $5 \mathrm{t} \mathrm{ha}^{-1}$ ), $\mathrm{T}_{4}$ (Biomix + Vermicompost @ $\left.5 \mathrm{t} \mathrm{ha}^{-1}\right), \mathrm{T}_{5}$ $\left(50 \% \mathrm{RDN}+\right.$ Vermicompost @ $\left.5 \mathrm{t} \mathrm{ha}^{-1}\right), \mathrm{T}_{6}\left(75 \% \mathrm{RDN}+\right.$ Vermicompost @ $\left.5 \mathrm{t} \mathrm{ha}^{-1}\right), \mathrm{T}_{7}$ $\left(50 \% \mathrm{RDN}+\right.$ Biomix + Vermicompost @ $\left.5 \mathrm{t} \mathrm{ha}^{-1}\right), \mathrm{T}_{8}(75 \% \mathrm{RDN}+$ Biomix+ Vermicompost @ $\left.5 \mathrm{t} \mathrm{ha}^{-1}\right), \mathrm{T}_{9}(\mathrm{RDN})$ and $\mathrm{T}_{10}\left(\mathrm{RDN}+\right.$ Biomix + Vermicompost @ $5 \mathrm{t} \mathrm{ha}^{-}$ $\left.{ }^{1}\right)$. Among various nitrogen management practices treatments $\mathrm{T}_{10}$ recorded significantly higher growth parameters viz. [plant height $(\mathrm{cm})$, number of tillers / m.r.l. and dry matter accumulation/plant (g/plant)] of barley. Treatment $\mathrm{T}_{8}(75 \% \mathrm{RDN}+$ Biomix + Vermicompost @ 5 $\mathrm{ha}^{-1}$ ) was at par with treatment $\mathrm{T}_{9}(\mathrm{RDN})$ and $\mathrm{T}_{10}(\mathrm{RDN}+$ Biomix + Vermicompost @ $5 \mathrm{t} \mathrm{ha}^{-1}$ ) in terms of growth of barley. Treatment $\mathrm{T}_{10}$ took highest number of days to flag leaf emergence, booting, anthesis and maturity as compared to other treatments. But days taken to emergence and tillering of barley was not influenced significantly due to various combinations of nitrogen fertilizer, biomix and vermicompost.

\section{Introduction}

Barley (Hordeum vulgare L.) is one of the most important foods and feed crop of the world. It is also an industrial crop which is the oldest cereal of the world. Barley is fourth most important cereal crop of world after wheat, rice and maize. It is grown throughout the tropical and region of the earth. It is a versatile crop which is quite hardy also and can be successfully grown in adverse agroclimatic conditions like salinity, alkalinity and drought. Barley is not only used for human food and feed for livestock but also used in the manufacture of malt extract which is further utilized for brewing, distillation and baby foods, cocoa malt drinks and also in Ayurvedic medicines. It gives higher response 
to various nitrogenous fertilizers than wheat but in case of barley fertilization, one cannot go for higher doses of nitrogenous fertilizers. In India increasing dose of nitrogen results in increasing absorption of nitrogen by the barley plants and consequently higher protein content in grain, which is an undesirable feature from point of view of malting quality.

Barley has immense potential as quality cereal especially for nutritional and medicinal point of view; hence, it is used in Ayurvedic medicines. Barley is also used to common cold, cure fever, asthma, skin diseases, urinary disorders, sore throat and digestive system.

Barley in developed countries is considered as a functional food and used in to make bakery products and recipes. In western countries, soups and porridges are prepared from dehusked grains of barley. It is preferably used in breweries. However, sugar syrups, cider and vinegar are other modes of utilizing barley.

The barley crop need less water and is more tolerant to salinity and alkalinity condition than other winter cereals. The crop possesses very high tolerance to drought and salt. Organic manures, which were perhaps the major sources of plant nutrient in traditional agriculture, received less emphasis with the advent of high analysis chemical fertilizers. Without detracting from the fact that chemical fertilizer will continue to be main instrument for quickening the pace for agriculture production the recent researches indicated that a judicious combination of organic manures and fertilize can better maintain the ling-term soil fertility and sustain high levels of Vermicompost, is a stabilized organic materials made by earthworms and microorganisms, have been reported to improve plant germination growth and yields in greenhouse crops (Edwards et al., 2004).
Biofertilizers are the preparations which contain living cells of efficient strains of various microorganisms that enhance uptake of nutrients by their interaction in the rhizosphere when applied through soil or seed treatment. There are various types of biofertilizers like Rhizobium, Azospirillum, Azotobacter, Blue green algae and Azolla. Biofertilizers add nutrients in soil through the natural processes of nitrogen fixation, solubilizing phosphorus, and stimulating plant growth through the synthesis of growthpromoting substances. Biofertilizers play an important role in the plant growth as well as they bring down the cost of chemical fertilizers e.g nitrogen phosphorous, and potassium. Microorganisms present in biofertilizer restore the nutrient cycle and build up soil OM. Inoculation of bacteria like Azotobacter, Pseudomonas and Bacillus has synergic and additive effects on plant growth besides reducing the cost of cultivation.

Biomix inoculants contain a combination of Nitrogen fixers, Phosphorus solubilisers and PGPR It is a low cost input technology that contributed to pollution free environment. It is found to enhance the growth of cereals, oilseeds and legumes better and save about $20-25 \%$ inorganic fertilizers such as nitrogenous and phosphorus in case of rice, cotton, chilli, groundnut, soybean and pulses.

Due to continuous cultivation of barley crops with recommended dose of chemical fertilizers only, the productivity of soils has decreased and now time has come to figure out the right and well matched level of chemical fertilizers with various organic sources of nutrients like inoculations, vermicompost, FYM etc. Keeping the above aspects in view, the present investigations "Growth and phenology of barley as influenced by various nutrient management practices" was planned. 


\section{Materials and Methods}

The Field experiment was conducted during rabi season of 2017-2018 at the Agronomy Research Farm of Chaudhary Charan Singh Haryana Agricultural University, Hisar which is situated at longitude of $75^{\circ} 46^{\prime}$ East, latitude of $29^{\circ} 10^{\prime}$ North and an elevation of $215.2 \mathrm{~m}$ above mean sea level in subtropical climate zone of the country. The present experiment was laid out in sandy loam soil $(62.8 \%$ sand, $19.5 \%$ silt and $16.9 \%$ clay) which is slightly alkaline in reaction, low in organic carbon and nitrogen and medium in available phosphorus and potassium. The experiment was laid out in Randomized Block Design replicated thrice with ten different treatments viz. $\quad \mathrm{T}_{1}$ (Control), $\quad \mathrm{T}_{2}$ (Biomix), $\quad \mathrm{T}_{3}$ (Vermicompost @ $5 \mathrm{t} \mathrm{ha}^{-1}$ ), $\mathrm{T}_{4}$ (Biomix + Vermicompost@5 tha $\left.{ }^{-1}\right), \mathrm{T}_{5}(50 \% \mathrm{RDN}+$ Vermicompost @ $\left.5 \mathrm{tha}^{-1}\right), \mathrm{T}_{6}(75 \% \mathrm{RDN}+$ Vermicompost @ $\left.5 \mathrm{t} \mathrm{ha}^{-1}\right), \mathrm{T}_{7}(50 \% \mathrm{RDN}+$ Biomix + Vermicompost @ $\left.5 \mathrm{t} \mathrm{ha}^{-1}\right), \mathrm{T}_{8}(75 \%$ $\mathrm{RDN}+$ Biomix+Vermicompost @ $\left.5 \mathrm{t} \mathrm{ha}^{-1}\right)$, $\mathrm{T}_{9}$ (RDN) and $\mathrm{T}_{10}$ (RDN + Biomix + Vermicompost@5 $\mathrm{t} \mathrm{ha}^{-1}$ ). Prior to sowing, the seed pertaining to inoculated plots was treated with Biomix culture obtained from Department of Microbiology, CCS Haryana Agricultural University, Hisar, as per treatment. The seed was wetted with sugar solution and $50 \mathrm{ml}$ of bio inoculants biomix was used as per the recommendation. The treated seed was kept in shade for the completion of inoculation. Both treated and untreated seeds were sown as per the treatments. Sowing was done manually with the help of hand plough by pora method at about $5.0 \mathrm{~cm}$ depth by drilling in rows using $90 \mathrm{~kg}$ seed ha $\mathrm{h}^{-1}$ and spacing of $22 \mathrm{~cm}$ between rows on $1^{\text {st }}$ December 2017. Harvesting was done with the help of sickles manually by cutting the plants from the net area of each plot separately on $20^{\text {th }}$ April 2018. Full dose of Phosphorous and Potassium and half of nitrogen as per treatment were applied as broadcast and mixing in soil through DAP, MOP and urea, respectively before sowing of barley at the time of field preparation. Remaining half of nitrogen was top dressed at first irrigation. Vermicompost @ $5 \mathrm{t} \mathrm{ha}^{-1}$ was applied as per treatment by incorporation in soil before sowing of barley crop. The other cultural practices were carried out as recommended for the crop. Three plants in each plot were tagged after germination used to record the number of days taken for initiation of different phenophases i.e. Days to emergence, Days to $50 \%$ tillering, Days to $50 \%$ heading, Days to 50\% anthesis and Days taken to maturity. From each plot five representative plants were selected randomly and tagged for recording the effect of different treatments on various growth attributes. The significance of treatment effects as well as significance of differences between means of two treatments was computed with the help of " $F$ " (variance ratio) test. Critical differences (CD) were sorted out as described by Gomez and Gomez (1983) as follows:

$$
\begin{aligned}
& \mathrm{CD}=\sqrt{\frac{\text { EMS } \times 2}{\mathrm{n}}} \times \mathrm{t} \text {-value for error d.f. at } 5 \% \text { level of significance } \\
& \text { Where, } \\
& \mathrm{CD}=\text { Critical difference } \\
& \mathrm{n} \quad=\text { Number of observations of that factor for which } \mathrm{CD} \text { is to be calculated. } \\
& \mathrm{t}=\text { Value of Fisher's table for error degree of freedom at } 5 \% \text { level of significance. }
\end{aligned}
$$

\section{Results and Discussion}

\section{Phenology}

There were no significant differences in the days taken to emergence and tillering of barley due to various combinations of nitrogen fertilizer, biomix and vermicompost because at the time of emergence, seedling derived nutrients from the storage organs and hence nitrogen levels had no significant influence on the seedling to emergence stage 
In the higher doses of fertilizer treatments 2-3 days more were taken as compared to control because of better root development or more prominent growth of vegetative phase of the crop. Days taken to tillering were between 30.12-33.28 DAS and anthesis between 79.09-89.35 DAS. Perusals of data also indicated that treatment $\mathrm{T}_{10}(\mathrm{RDN}+$ Biomix + Vermicompost @ $5 \mathrm{t} \mathrm{ha}^{-1}$ ) took highest number days to flag leaf emergence, booting, anthesis and maturity as compared to other treatments. Nitrogen application increased the vegetative growth as nitrogen application increase the photosynthetic activity and the leaves remain functional for a longer period which improved plant height and dry matter accumulation which ultimately delayed the ear heading in barley. Minimum number of days to flag leaf emergence, booting, anthesis and maturity were recorded in treatment $T_{1}$ (Control). No fertilizer application in treatment $T_{1}$ had induced early flowering and early maturity as compared to higher fertility treatments $\left(\mathrm{T}_{10}, \mathrm{~T}_{9}\right.$ and $\left.\mathrm{T}_{8}\right)$ which on the other hand has prolonged the growth, flowering and maturity duration. It might be due to release of growth hormones by biomix which results in more vegetative growth stage and hence delay in phenological stages of crop growth. Kumar (2005) also revealed that days taken to $50 \%$ anthesis with the application of $125 \%$ recommended dose of RDN were highest which differed significantly from other treatments except $100 \%$ RDN + Biomix. Days taken to maturity of barley were in treatment $\mathrm{T}_{10}(\mathrm{RDN}+$ Biomix + Vermicompost@5 t ha ${ }^{-1}$ ) being at par with treatment $\mathrm{T}_{4}$ to $\mathrm{T}_{9}$ were significantly higher than other treatments.

Increase in nitrogen application resulted in increase in photosynthetic efficiency of the plant which ultimately delayed the maturity of the crop. Further, days taken to maturity were reduced by five days under treatment $T_{1}$ (Control) as compared to $\mathrm{T}_{10}(\mathrm{RDN}+$ Biomix
+Vermicompost @ $5 \mathrm{t} \mathrm{ha}^{-1}$ ). Days taken to maturity of barley were between 136.96141.09 DAS. Similarly, Malik (2017) in Hisar also concluded that days to flowering and maturity are delayed due to seed inoculation to various combinations of bio fertilizers.

\section{Growth parameters}

Lowest plant height of barley was recorded in treatment $\mathrm{T}_{1}$ (Control) at all the stages of crop growth (Table 2). At low level of nitrogen, plant might have not been able to meet nitrogen requirement, ultimately resulted in stunted growth. Significantly taller plants were recorded in treatment $\mathrm{T}_{10}$ at all the stages of crop growth. However, the difference in plant height of barley in treatment $\mathrm{T}_{8}, T_{9}$ and $\mathrm{T}_{10}$ at $30 \mathrm{DAS}, T_{9}$ and $\mathrm{T}_{10}$ at $60 \mathrm{DAS}$ and $\mathrm{T}_{6}$ to $\mathrm{T}_{10}$ at $90 \mathrm{DAS}$ were not significant. This might be because of higher nitrogen supply which enhanced the photosynthesis rate and better translocation of assimilates by plant at higher nitrogen application.

The increase in plant height due to seed inoculation with biomix may also be due to secretion of various growth hormones by microorganisms. Results reported by Rathore et al., (2003), Kumar (2005) and Shirinzadeh et al., (2013) were also similar. Taller plants in treatment containing vermicompost may be owing to increased supply of plant growth regulators, multi-nutrients and beneficial microflora released from vermicompost in addition to the most favorable conditions with respect to physico-chemical and biological properties of the soil. At higher level of nitrogen, crop absorbed sufficient amount of $\mathrm{N}$, resulting in better growth parameters such as plant height, dry matter accumulation, number of tillers. Nitrogen application increased plant height (Moreno et al., 2003; Meena et al., 2012) and tillering, which ultimately led to higher dry matter production. 
Table.1 Effect of integrated nutrient management practices on different phenological stages (DAS) of barley

\begin{tabular}{|c|c|c|c|c|c|c|}
\hline \multirow[t]{2}{*}{ Treatments } & \multicolumn{6}{|c|}{ Days to } \\
\hline & Emergence & Tillering & $\begin{array}{c}\text { Flag leaf } \\
\text { emergence }\end{array}$ & Booting & Anthesis & Maturity \\
\hline$T_{1}$ : Control & 6.89 & 30.12 & 66.23 & 70.01 & 79.09 & 136.96 \\
\hline$T_{2}:$ Biomix & 6.93 & 30.67 & 67.33 & 70.13 & 79.23 & 137.89 \\
\hline $\mathrm{T}_{3}:$ Vermicompost @ $5 \mathrm{t} \mathrm{ha}^{-1}$ & 7.09 & 30.99 & 67.36 & 71.33 & 80.65 & 137.53 \\
\hline $\mathrm{T}_{4}:$ Biomix + Vermicompost @ $5 \mathrm{t} \mathrm{ha}^{-1}$ & 7.13 & 31.12 & 68.02 & 72.89 & 81.11 & 138.11 \\
\hline $\mathrm{T}_{5}: 50 \% \mathrm{RDN}+$ Vermicompost @ $5 \mathrm{t} \mathrm{ha}^{-1}$ & 7.21 & 31.24 & 69.31 & 73.19 & 82.45 & 138.41 \\
\hline $\mathrm{T}_{6}: 75 \% \mathrm{RDN}+$ Vermicompost @ $5 \mathrm{t} \mathrm{ha}^{-1}$ & 7.39 & 31.56 & 71.14 & 74.08 & 84.13 & 139.05 \\
\hline $\begin{array}{l}\mathbf{T}_{7}: \mathbf{5 0} \% \mathrm{RDN}+\text { Biomix + Vermicompost } \\
\text { @ } 5 \mathrm{tha}^{-1}\end{array}$ & 7.47 & 32.36 & 71.68 & 74.66 & 85.67 & 139.84 \\
\hline $\begin{array}{l}\text { T}_{8}: 75 \% \text { RDN + Biomix+ Vermicompost } \\
\text { @ } 5 \mathrm{tha}^{-1}\end{array}$ & 7.57 & 32.63 & 72.19 & 75.09 & 86.12 & 140.36 \\
\hline$T_{9}: \operatorname{RDN}\left(60 \mathrm{~kg} \mathrm{~N} \mathrm{ha}^{-1}\right)$ & 7.61 & 33.19 & 72.53 & 77.46 & 88.18 & 140.87 \\
\hline $\begin{array}{l}\text { T }_{10}: \text { RDN + Biomix + Vermicompost @ } 5 \mathrm{t} \\
\text { ha }^{-1}\end{array}$ & 7.79 & 33.28 & 73.09 & 79.29 & 89.35 & 141.09 \\
\hline SEm \pm & 0.32 & 0.51 & 0.75 & 0.83 & 0.94 & 1.01 \\
\hline CD at $5 \%$ & NS & NS & 2.25 & 2.49 & 2.82 & 3.03 \\
\hline
\end{tabular}

Table.2 Plant height of barley as influenced by integrated nutrient management practices at different growth stages

\begin{tabular}{|c|c|c|c|c|}
\hline \multirow[t]{2}{*}{ Treatments } & \multicolumn{4}{|c|}{ Plant height (cm) } \\
\hline & $\begin{array}{c}\text { 30 } \\
\text { DAS }\end{array}$ & $\begin{array}{c}60 \\
\text { DAS }\end{array}$ & $\begin{array}{c}90 \\
\text { DAS }\end{array}$ & $\underset{\text { Maturity }}{\text { At }}$ \\
\hline$T_{1}$ : Control & 21.11 & 52.83 & 75.08 & 79.14 \\
\hline$T_{2}:$ Biomix & 22.86 & 56.27 & 82.16 & 85.78 \\
\hline $\mathrm{T}_{3}:$ Vermicompost @ $5 \mathrm{t} \mathrm{ha}^{-1}$ & 24.34 & 59.43 & 85.23 & 88.22 \\
\hline $\mathrm{T}_{4}:$ Biomix + Vermicompost @ $5 \mathrm{t} \mathrm{ha}^{-1}$ & 25.56 & 60.22 & 86.76 & 90.15 \\
\hline $\mathrm{T}_{5}: 50 \%$ RDN + Vermicompost @ $5 \mathrm{t} \mathrm{ha}^{-1}$ & 25.74 & 62.63 & 87.55 & 91.02 \\
\hline $\mathrm{T}_{6}: 75 \%$ RDN + Vermicompost @ $5 \mathrm{t} \mathrm{ha}^{-1}$ & 27.09 & 65.54 & 90.19 & 92.29 \\
\hline $\mathrm{T}_{7}: 50 \%$ RDN + Biomix + Vermicompost @ $5 \mathrm{tha}^{-1}$ & 27.83 & 66.94 & 91.11 & 93.62 \\
\hline $\mathrm{T}_{8}: 75 \%$ RDN + Biomix + Vermicompost @ $5 \mathrm{t} \mathrm{ha}^{-1}$ & 28.44 & 67.36 & 91.72 & 93.99 \\
\hline$T_{9}: \operatorname{RDN}\left(60 \mathrm{~kg} \mathrm{~N} \mathrm{ha}^{-1}\right)$ & 29.09 & 70.58 & 92.34 & 96.09 \\
\hline $\mathrm{T}_{10}: \mathrm{RDN}+$ Biomix + Vermicompost @ $5 \mathrm{t} \mathrm{ha}^{-1}$ & 29.56 & 72.19 & 93.09 & 97.01 \\
\hline SEm \pm & 0.45 & 0.88 & 1.01 & 1.22 \\
\hline CD at $5 \%$ & 1.37 & 2.63 & 3.04 & 3.68 \\
\hline
\end{tabular}


Table.3 Dry matter accumulation per plant of barley as influenced by integrated nutrient management practices at different growth stages

\begin{tabular}{|c|c|c|c|c|}
\hline \multirow[t]{2}{*}{ Treatments } & \multicolumn{4}{|c|}{ Dry matter accumulation $\left(\mathrm{g} / \mathrm{m}^{2}\right)$} \\
\hline & $\begin{array}{c}\text { 30 } \\
\text { DAS }\end{array}$ & $\begin{array}{c}\text { 60 } \\
\text { DAS }\end{array}$ & $\begin{array}{c}90 \\
\text { DAS }\end{array}$ & $\begin{array}{c}\text { At } \\
\text { Maturity }\end{array}$ \\
\hline $\mathbf{T}_{1}$ : Control & 29.2 & 144 & 570 & 958 \\
\hline $\mathbf{T}_{2}:$ Biomix & 33.1 & 177 & 609 & 1161 \\
\hline $\mathbf{T}_{3}:$ Vermicompost @ $5 \mathrm{t} \mathrm{ha}^{-1}$ & 35.5 & 180 & 612 & 1189 \\
\hline $\mathbf{T}_{4}:$ Biomix + Vermicompost @ 5 t ha $^{-1}$ & 36.2 & 188 & 621 & 1250 \\
\hline $\mathrm{T}_{5}: 50 \% \mathrm{RDN}+$ Vermicompost @ $5 \mathrm{t} \mathrm{ha}^{-1}$ & 37.1 & 190 & 626 & 1281 \\
\hline $\mathrm{T}_{6}: 75 \% \mathrm{RDN}+$ Vermicompost @ $5 \mathrm{t} \mathrm{ha}^{-1}$ & 38.6 & 210 & 637 & 1302 \\
\hline $\mathrm{T}_{7}: 50 \% \mathrm{RDN}+$ Biomix + Vermicompost @ $5 \mathrm{t} \mathrm{ha}^{-1}$ & 39.7 & 213 & 642 & 1312 \\
\hline $\mathrm{T}_{8}: 75 \% \mathrm{RDN}+$ Biomix + Vermicompost @ $5 \mathrm{t} \mathrm{ha}^{-1}$ & 39.2 & 220 & 646 & 1321 \\
\hline$T_{9}: \operatorname{RDN}\left(60 \mathrm{~kg} \mathrm{~N} \mathrm{ha}^{-1}\right)$ & 40.2 & 224 & 647 & 1324 \\
\hline $\mathrm{T}_{10}: \mathrm{RDN}+$ Biomix + Vermicompost @ $5 \mathrm{t} \mathrm{ha}^{-1}$ & 40.8 & 229 & 651 & 1337 \\
\hline $\mathrm{SEm} \pm$ & 0.7 & 7.4 & 10.2 & 55.8 \\
\hline CD at $5 \%$ & 2.1 & 22.8 & 31.8 & 172.7 \\
\hline
\end{tabular}

Fig.1 Effect of integrated nutrient management practices on no. of tillers of barley

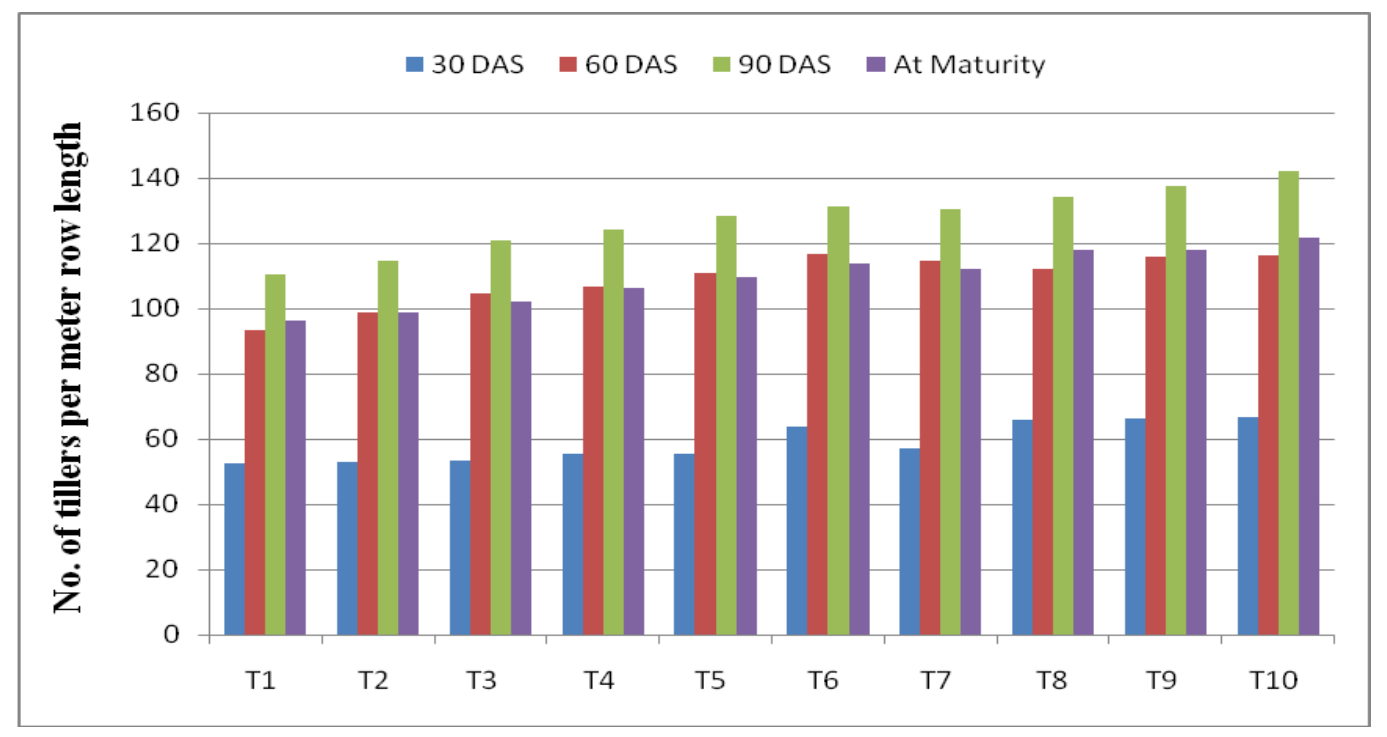

Effective tillering in any crop depends primarily on soil physical conditions that were superior due to addition of vermicompost (Kakraliya et al., 2016). Among various combinations of nitrogen fertilizer, biomix and vermicompost treatment $\mathrm{T}_{10}$ at all the stages of crop growth also resulted in highest dry matter accumulation and tillers per metre row length (fig.1). The difference in dry matter accumulation at 30 DAS in treatment $T_{7}$ to $T_{10}$ was significant (Table 3). Treatment $T_{10}$ resulted in highest number of tillers/mrl at all the stages of crop growth. The difference in dry matter accumulation of barley may be due to beneficial effects of combined application of 
inorganic fertilizers, organic manures along with bio-fertilizers. This is might be due to the fact that addition of chemical fertilizer, vermicompost and biomix in conjunction with all essential macro and micro nutrients and their uptake by the barley crop and as a resulted effect of higher dry matter production and their translocation in plant parts. Similar findings have been reported by several research workers (Patel et al., 2012 and Kumar et al., 2014). Various combinations of nitrogen fertilizer, biomix and vermicompost increased the growth of the barley crop resulting in more dry matter accumulation by secreting plant growth hormones. The increase in tillers of barley in INM might be due adequate quantity and balanced proportion of plant nutrient supplied to the crop as per need during the growing period resulting in favorable environment for crop growth. Similar results also observed by and Suthar (2006). Corroborative findings have also been reported by Upadhyay and Vishwakarma (2014).

In conclusion among the various combinations of nitrogen fertilizer, vermicompost and Azotobacter treatments $\mathrm{T}_{10}$ recorded significantly taller plants, higher dry matter accumulation/plant (g/plant)] and no. of tillers per plant. Performance in terms of growth of barley in treatment $\mathrm{T}_{8}(75 \% \mathrm{RDN}$ +Biomix+Vermicompost @ 5t ha ${ }^{-1}$ ) was at par with treatment $\mathrm{T}_{9}(\mathrm{RDN})$ and $\mathrm{T}_{10}(\mathrm{RDN}+$ Biomix + Vermicompost @ 5t $\left.\mathrm{ha}^{-1}\right)$. Treatment $\mathrm{T}_{10}$ took highest number of days to flag leaf emergence, booting, anthesis and maturity as compared to other treatments. But various combinations of nitrogen fertilizer, biomix and vermicompost failed to produce any significant variation in days taken to emergence and tillering.

\section{References}

Edney, M.J., O ${ }^{e e}$ Donovan, J.T., Turkington, T.K., Clayton, G.W., McKenzie, R.H.,
Juskiw, P.E., Lafond, G.P., Brandt, S., Grant, C.A., Harker, K.N., Johnson, E.N., and May, W.E. (2012). Effects of seeding rate, nitrogen rate and cultivar on barley malt quality. Journal of the Science of Food and Agriculture, 92, 2672-2678.

Kakraliya, S.K. Sutaliya, J.M. Singh, L.K. Singh, I., Jat, H.S. and Jat, M.L. (2016). Developing portfolios of climate smart agriculture practices for a rice-wheat cropping systems in western indo-gangetic plains of south Asia. $4^{\text {th }}$ International Agronomy Congress, Nov.22-26, 2016, New Delhi, India.1: 88-89.

Kumar, Pradeep., Singh, R. S., Paliwal, Dinesh., and Kumar, Sushil (2014). Integrated nutrient management in pearl millet (Pennisetum glaucum) wheat (Triticum aestivum) cropping sequence in semi-arid condition of India. International Journal of Agricultural Sciences, 10 (1): 96-101.

Malik, Priti (2017). Response of barley to fertilizer levels and different combinations of biofertilizers. Ph.D. Thesis, CCS HAU, HISAR.

Meena, L. R., Mann, J. S., and Meena, S. L. (2012) Effect of levels and mode of nitrogen application on dual purpose barley (Hordeum vulgare L.) under semi-arid condition. Indian Journal of Agronomy, 57 (2), 168-170.

Moreno, A., Moreno, M.M., Ribas, F. and Cabello, M.J. (2003) Influence of nitrogen fertilizer on grain yield of barley (Hordeum vulgare L.) under irrigated conditions. Spanish Journal of Agricultural Research, 1(1), 91-100.

Patel, C.B., Singh, R.S., Yadav, M.K., Singh, S.K., Singh, M.K., Singh, K.K. and Mall, R.K. (2012). Response of different wheat (Triticum aestivum L. emend Fiori \& Paol.) genotypes to various nitrogen levels under late sown 
conditions of Eastern Uttar Pradesh. Environment and Ecology, 30 (3C): 1192-1196.

Rathore, V.S., Singh, P., and Gautam, R.C. (2003) Influence of planting patterns and integrated nutrient management on yield, nutrient uptake and quality of rainfed pearl millet. Annals of Agriculture Research, 25 (3), 373-376.

Shirinzadeh, A., Soleimanzadeh, H., and Shirinzadeh, Z. (2013) Effect of seed priming with plant growth promoting rhizobacteria (PGPR) on agronomic traits and yield of barley cultivars. World Applied Sciences Journal, 21
(5), 727-731.

Suthar, S.L. (2006). Effect of sowing methods, nitrogen and chemical weed control on wheat (Triticum aestivum L.). MSc Thesis, Maharana Pratap University of Agriculture and Technology, Udaipur.

Upadhyay, V. B. and Vishwakarma, S. K. (2014). Long-term effect of integrated nutrient management in rice (Oryza sativa) - wheat (Triticum aestivum) cropping system. Indian Journal of Agronomy, 59 (2): 209-214.

\section{How to cite this article:}

Sandeep Kumar, Meena Sewhag, Shweta, Uma Devi and Neelam. 2020. Growth and Phenology of Barley as Influenced by Various Nutrient Management Practices. Int.J.Curr.Microbiol.App.Sci. 9(07): 3920-3927. doi: https://doi.org/10.20546/ijcmas.2020.907.459 